ppi $201502 Z U 4645$

Esta publicación científica en formato digital es continuidad de la revista impresa ISSN-Versión Impresa 0798-1406 / ISSN-Versión on line 2542-3185Depósito legal pp $197402 Z$ U34
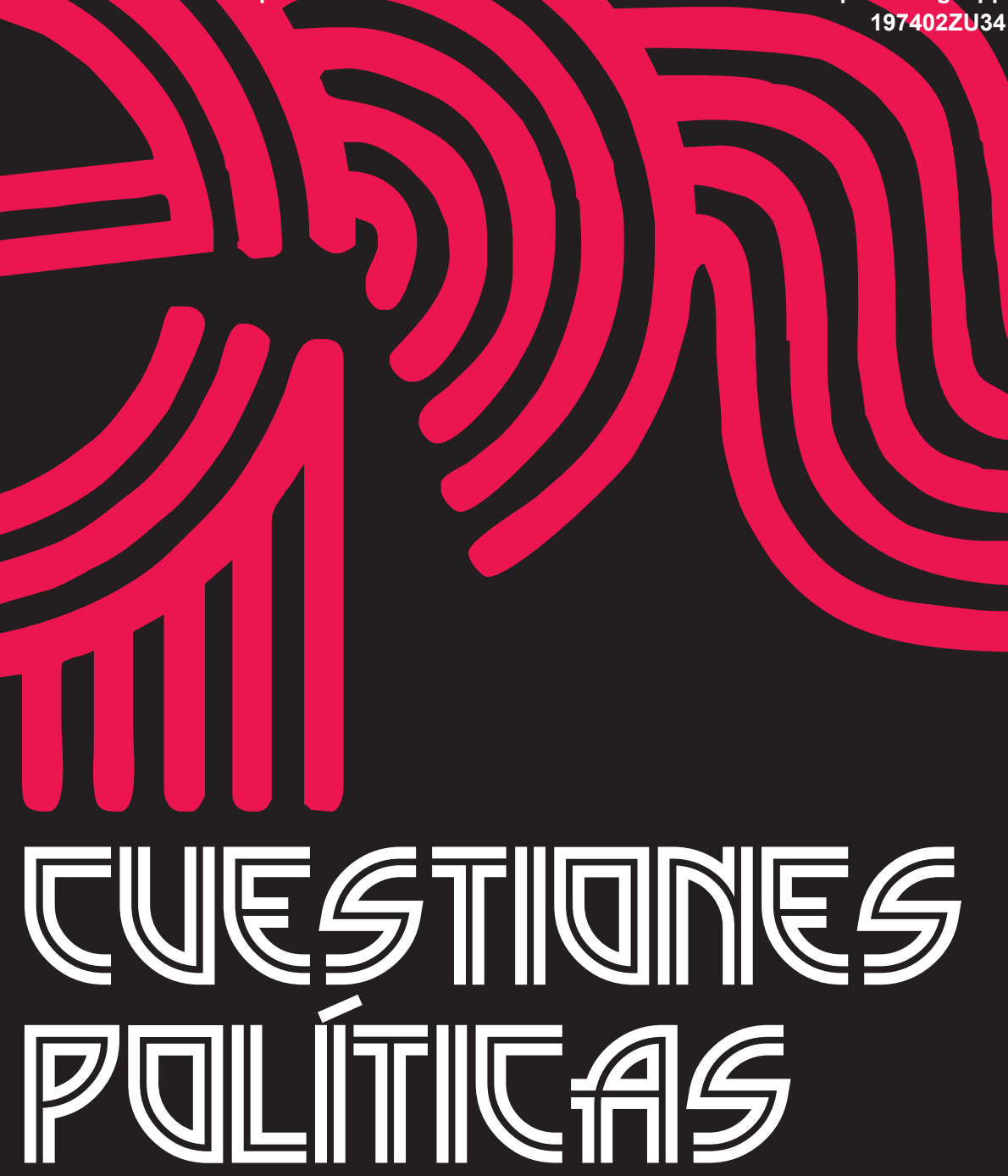

Instituto de Estudios Políticos y Derecho Público "Dr. Humberto J. La Roche" de la Facultad de Ciencias Jurídicas y Políticas de la Universidad del Zulia Maracaibo, Venezuela
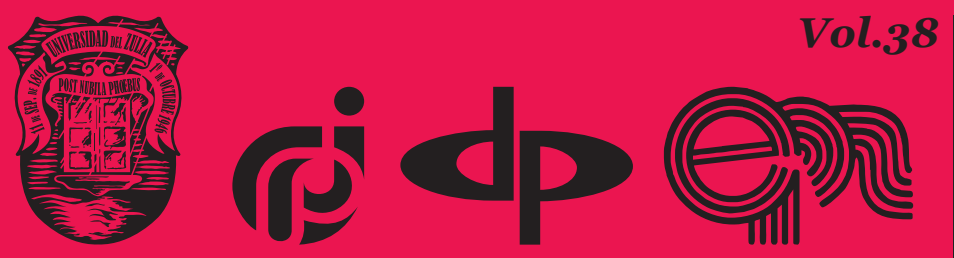

$N^{\circ}$ Especial 2da Parte 2020 


\title{
Innovation IT-Payment Technologies as a Know-how and an Object of Intellectual Property Rights
}

\author{
DOI: https://doi.org/10.46398/cuestpol.382e.39
}

\begin{abstract}
Ernest Gramatskyy *
Inha Kryvosheyina **

Volodymyr Makoda ***

Liydmyla Panova ****
\end{abstract}

\begin{abstract}
The modern society necessitates the introduction of new ITsolutions to meet its needs. With the spread of know-how, the need for its detailed analysis with the further determination of the direction of development. The purpose is to carry out an analysis of the introduction and functioning of know-how, as well as to determine the vectors of its use, taking into account the needs of participants in legal relations arising in this area. The subject of research - information technologies (know-how) as objects of intellectual property rights in their use. The methodological basis consists of the method of analysis, the method of synthesis, the dialectical method, the comparativelegal method, the system method, and the logical-legal method. The result of this work is to identify the importance of the information technologies in everyday life of modern society and the level of popularity of their use, outlining possible vectors of development in the economics in the direction of digitalization and justification of the need to improve the provisions of current legislation within the considered topic, expressing the idea of the direction of innovative information policy in the direction of active use of blockchain and maximum compliance with the protection of personal data
\end{abstract} of customers.

Keywords: information technology; modernization of payment technologies; Know-how; blockchain; legal computing.

* Ph. D., Associate Professor of Civil Law Department, Taras Shevchenko National University of Kyiv, Address, Kyiv, Ukraine. ORCID ID: https://orcid.org/oooo-0oo3-1260-2888. Email: emg@ gramatskiy.com

** Ph. D., Associate Professor of Intellectual Property Department, Taras Shevchenko National University of Kyiv, Address, Kyiv, Ukraine. ORCID ID: https://orcid.org/oooo-0003-3630-2257. Email: i.kryvosheyina@gmail.com

*** Ph. D., Associate Professor of Civil Law Department, Taras Shevchenko National University of Kyiv, Address, Kyiv, Ukraine. ORCID ID: https://orcid.org/oooo-ooo3-4408-1925. Email: Makodav@ukr. net

**** Ph. D., Associate Professor of Civil Law Department, Taras Shevchenko National University of Kyiv, Address, Kyiv, Ukraine. ORCID ID: https://orcid.org/oooo-ooo2-9524-7529. Email: LPanova@i.ua. 


\section{Tecnologías de pago del Know-how y objeto de los derechos de propiedad intelectual}

\section{Resumen}

El objetivo de la investigación fue realizar un análisis de la introducción y funcionamiento del know-how, así como determinar los vectores de su uso, teniendo en cuenta las necesidades de los participantes en las relaciones jurídicas que surgen en este ámbito. El tema de la investigación las tecnologías de la información (know-how) como objetos de derechos de propiedad intelectual en su uso. La base metodológica estuvo conformada por el método de análisis, el método de síntesis, el método dialéctico, el método comparativo-legal, el método del sistema y el método lógico-legal. Como conclusión destaca la importancia de las tecnologías de la información en la vida cotidiana de la sociedad moderna con énfasis especial en su nivel de popularidad de su uso, delineando posibles vectores de desarrollo en la economía en la dirección de la digitalización y justificación de la necesidad de mejorar las disposiciones de la legislación vigente dentro del tema considerado. También resalta la idea de la dirección de la política de información innovadora en la dirección del uso activo de blockchain por su máximo cumplimiento de la protección de datos personales de los clientes y usuarios.

Palabras clave: tecnología de la información; modernización de las tecnologías de pago; Know-how; blockchain; informática jurídica.

\section{Introduction}

It is known that law, as a system of mandatory rules of conduct introduced or sanc-tioned by the state, is the most effective regulator of public relations. No other social norms, such as traditions, customs, norms of morality, etc., are able to regulate and ensure the protection of various social relations as the rules of law do (Tkalych et al., 2020). Only taking into account the interests of as many members of the human community as possible while adhering to clear rules and principles of coexistence can lead to the development of a full-fledged society and state (Shyshka and Tkalych, 2020).

In the context of globalization, modern society is developing rapidly. Today's challenges are related to the increase of human needs, which in turn determines the desire to ensure their dynamic and high-quality satisfaction. Therefore, there is an urgent need to modernize, including the banking sector. 
The specificity of the modification of the economic sector is manifested primarily by its unique features and characteristics, which are not defined exclusively by legal issues but go beyond them, being at the intersection of different branches of law and the whole spectrum of social life in its broad interpretation (Aristova and Chernadchuk, 2012).

The modernization of the economic sector is primarily related to information technologies, which are essentially objects of intellectual property rights and are designed to improve it by adapting to the growth rate and the nature of demand from users of such a system. Thus, the introduction and further application of information technologies in the, for example, banking sector aims to expand the range of users (customers), maintain the competitiveness of the bank, attract foreign investment, and increase the reputation of the banking sector of Ukraine abroad.

It is worth noting that among all the objects of intellectual property rights, know-how has the closest relation to innovative information technologies, as it is usually the official "design" of most innovative developments. The role and importance of know-how (in the age of rapid scientific and technological progress) is constantly growing every year, absorbing more and more important areas of public life. Further, the popularity of knowhow in this sector is justified by the possibility of combining a set of different types of knowledge, which are the basis of know-how. Thus, know-how can combine information on commercial processes, management methods, technological assets, databases, etc. Thus, trying to reach a new level of economic relations, institutions are actively implementing information know-how in the main aspects of their activities.

The purpose of the work is to carry out an analysis of the introduction and functioning of know-how, as well as to determine the vectors of its use, taking into account the needs of participants in legal relations arising in this area. The object of the study is the relationship that develops within the innovation activities, in particular, the introduction of know-how. The subject of research - information technologies (know-how) as objects of intellectual property rights in their use.

\section{The material and method}

\subsection{Methodology}

The methodological basis of the work were the methods of analysis and synthesis, the dialectical method, the method of generalization, the formallegal method, the system method, historical-legal method and the logicallegal method. 
Thus, using the methods of analysis and synthesis explored the general principles of regulating the introduction and use of information technologies in the banking sector, by studying the political course of the state, existing legislation, and the general state of the banking market.

What is more, with the help of the analysis, it became possible to characterize innovative information technologies (know-how) and processes associated with their application, highlight the main objectives of their introduction, signs of know-how in the banking sector, and differences with other objects of intellectual property rights. The synthesis served as a basis for combining original ideas, principles, and developments to identify the most promising way to improve the implementation of innovations in the banking sector.

Moreover, the dialectical method was used to establish the true purpose of modern innovation IT-processes taking place in the banking sector by resolving contradictions in the outdated postulates of the existing banking system, as well as the main characteristics of innovative information technology as an object of intellectual property law, which interacts with other elements of the legal system, develops, changes in accordance with the general trends of society and the legal sphere.

The system method revealed the general properties, connections, and patterns that arise when using innovative information technologies in the banking sector. As well as help to identify the problems faced by banks in the implementation of know-how and the dependence of the banking sector on changes in society and legal changes.

Furthermore, the comparative legal method helped to trace the development of the legal basis for regulating the market of banking products and services for the introduction of innovations IT, while the historical-legal method reveals drawn changes in the understanding and perception of know-how both within the general application of this concept and in regulations. The formal-legal method has become indispensable in interpreting the content of basic concepts, their basic characteristics, as well as the interpretation of legal norms governing banking in general and the introduction of innovative information technologies in particular.

The generalization method made it possible to identify the main problems and vectors of development of know-how in the activities of banks, as well as helped to conclude the study. The logical-legal method is reflected in the formulation of proposals for further improvement of the innovation information policy of banks. 
Ernest Gramatskyy, Inha Kryvosheyina, Volodymyr Makoda y Liydmyla Panova

522

Innovation IT-Payment Technologies as a Know-how and an Object of Intellectual
Property Rights

\subsection{Analysis of Recent Research and Findings}

As for the theoretical basis of the study, the following should be mention. The works of many specialists in various fields are devoted to the study of issues related to innovative information technologies in general and their use in the spheres of public life.

In particular, Begova (2009) paid attention to the interpretation of the concept of "know-how" in terms of the main objects of intellectual property rights. She determined that the know-how was part of a trade secret. Besides, Dmitrenko (2016) studied national legislation, case law, and legal doctrine to define the essence of the concept of "know-how" in Ukraine.

Kolosov (2017) devoted his scientific works to the study of the legal regime of know-how in terms of intellectual property rights and forecasting the future prospects of its use. He concluded that currently there is no single common definition of the concept of "secret of production (know-how)", and different countries have different meanings in this concept.

Kuntsevich (2005) considered know-how through the prism of its characteristics as an object of intellectual property rights. In his work, the scientist paid considerable attention to property rights to know-how, which resulted in the separation and division of the objects of these property rights into appropriate media on know-how and directly know-how as a tangible product.

In the general perception of the theoretical and legal features of protection and defense of know-how in comparison with trade secrets in the economic sphere made adjustments with his works Matveev (2015), who compared common and distinctive features of know-how and trade secrets, highlighted the characteristics of each of these atypical objects of intellectual property rights and proposed the basic principles of protection of know-how in Ukraine. They made a lot of effort to perceive know-how as a full-fledged and indispensable object of intellectual property rights in business. In particular, the know-how was classified according to the criterion of the nature of the institutions that use it, and the ratio of the transfer of innovative technologies and their commercialization was analysed. The problem of legal regulation of the IT-transaction was studied by Davydova, Orzikh, Samoylenko, Andronov, and Pysarenko (2019).

In turn, Svishchova, Cherepanova, and Loktionova (2017) also insisted on the position of active use of know-how in the daily activities of the business sphere. The above-mentioned scientists focused their attention on an atypical object of intellectual property - know-how, in connection with which they focused on its importance in doing business and the peculiarities of methods of its protection. 
Moreover, the popularity of the study and general issues of modernization of the banking sector is not inferior.

Thus, Shmigelska (2014) studied the essence, content, and prospects of banking IT. She noted that in many post-Soviet countries, the population is not prepared to accept banks as financial advisors on the use of IT in the banking sector (mobile banking, Internet banking, scoring, etc.). This hinders the development of banks, limits their ability to increase competitiveness in global financial markets.

Moreover, Dominova (2016) analyzed the genesis and specifics of forms of electronic banking, without which it is now difficult to imagine everyday life. According to her work, Internet banking and mobile banking have become the most popular and widespread in developed countries. These forms allow customers from anywhere in the world, at a convenient time for the client, to monitor the status of accounts and carry out a wide range of banking operations. At present, the attitude to the legal nature of knowhow differs on a theoretical level. In particular, the term "know-how" is similar to the concept of "trade secret". The know-how is a broader concept that covers both trade secrets and trade secrets. A trade secret is a way to protect know-how.

Thus, Begova (2019) distinguishes between the concept of know-how and trade secret in content - the nature of information, because she believes that the concept of the trade secret is much broader in scope and includes not only the results of intellectual creativity, but may contain information informative and even cognitive character. Instead, Nosik (2007) sees the difference in know-how in the criteria contained in EU legislation.

Zveruk and Tkachenko (2018) have made a significant contribution to understanding the importance of digitalization (modern technologies) for the introduction and formation of an innovative model of banking business development. The example of their research clearly illustrates the innovative model of doing business in the banking sector using digital and innovative IT, including electronic banking, mobile applications, services, atypical payment technologies, and blockchain.

Pidvysotsky (2014) in his research emphasized the interaction of banking institutions with their customers by applying modern information technologies and capabilities in such interaction. In particular, a practical analysis of how banks communicate with customers was carried out, as a result of which modern innovative channels of information exchange were identified (among which the Internet plays a key role).

Nevertheless, at the same time, the issue of the use of know-how in the banking sector cannot be considered completely exhausted, as many aspects of this multifaceted phenomenon still remain incompletely studied and studied, and these issues are raised in these articles. 
Ernest Gramatskyy, Inha Kryvosheyina, Volodymyr Makoda y Liydmyla Panova

\section{Results and discussion}

The banking sector plays an important role in organizing the economic space of each state and the international community as a whole, as it provides the economy with the necessary financial resources, ensuring the free movement of capital and lending to the economy, promoting business activities and more. That is why the banking sector must develop along with the current pace of modernization of the needs of society, where IT plays an important role.

Innovations - newly created (applied) and (or) improved competitive technologies (information technologies), products or services, as well as organizational and technical solutions of production, administrative, commercial or other nature, which significantly improve the structure and quality of production and (or) social sphere (Law of Ukraine, 2002).

It is worth noting that know-how is usually associated with solving a problem through the use of modern information technology because they are designed to meet the urgent needs of modern society - saving time and effort.

Banking innovations IT are the result of the bank's activities aimed at creating new products and technologies, as well as innovative methods of managing a banking institution to obtain additional income and competitive advantages (Law of Ukraine, 2002).

The growth in the percentage of informatization of banking services in the most developed countries of the world can be seen in the Fig. 1.

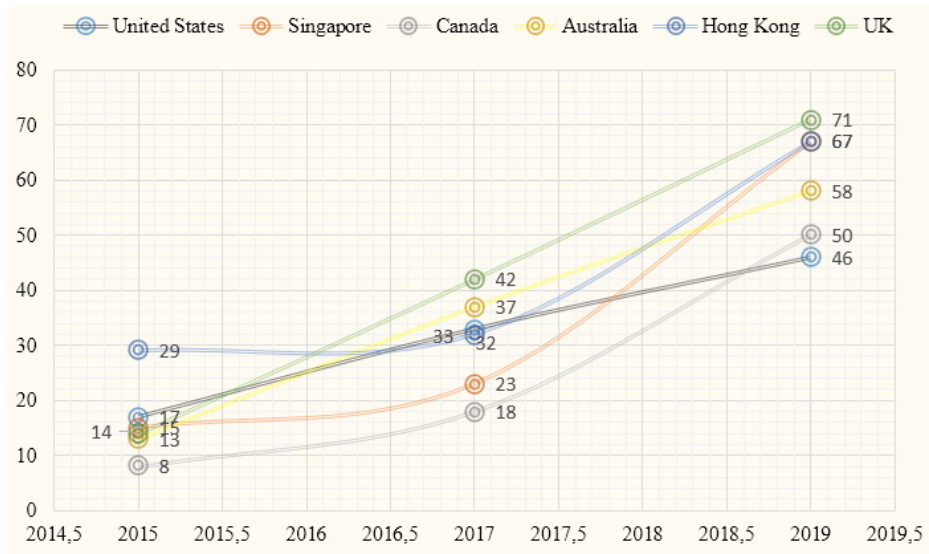

Fig. 1 The percentage of implementation of information technology in the banking sector (\%), data provided by Global FinTech Adoption Index (2020). 
Information technology in the banking sector are characterized by the following features (Fig. 2):

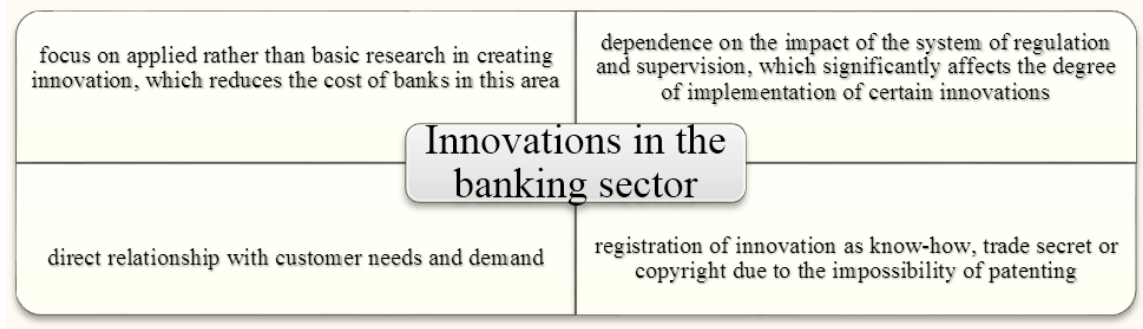

Fig. 2 The main features of the innovations in the banking sector (Own creation).

Innovations IT, in their essential parameters, are correlated with the objects of intellectual property rights, including know-how.

In the conventional sense, know-how is perceived as an innovation that has special value due to its unknown to others (Kolosov, 2017).

According to the authors, it is successful know-how definition, according to which the term "know-how" is information obtained through experience and testing, which is not well known or readily available on the date of the technology transfer agreement; is essential (important and useful for the production or provision of services); is defined (described enough to be able to verify its compliance with the criteria of obscurity and materiality) (Law of Ukraine, 2006).

Know-how in the field of IT is an object of intellectual property law, which does not have clearly defined legislation. The peculiarities of knowhow distinguish it from other objects, making it unconventional, and not allowing it to be assigned to one or another group of objects. At the same time, know-how in the field of IT as an object of intellectual property rights is characterized by novelty, commercial value, inaccessibility to other entities without the consent of the author.

In addition, for the possibility of use, and especially for the protection and defense of know-how require material embodiment, i.e. must meet the criterion of identity. Thus, the know-how should be recorded in a certain way: a method is described or recorded that will further allow verifying compliance with the criteria of secrecy, materiality, and usefulness (Romashko and Verba, 2013). 
As mentioned above, know-how must be in some way "formalized" in the object of property rights. Such an object may be a material medium of information about know-how (document, disk, etc.) and (or) a natural sample of any product, which is rare and is considered quite undesirable, and copies (circulation) of the original media; material products made according to specific know-how (Kuntsevich, 2005). Thus, the external form of know-how can be similar to both copyright and patent law.

Know-how in the field of IT cannot be considered various "trade secrets" relating to the cost of goods or services, plateau - or creditworthiness of enterprises, current accounting data, the terms of specific trade agreements, the content of advertising before its publication, etc. (Matveev, 2015).

In practice, know-how is closely linked to such an object of industrial property rights as trade secrets. According to the authors, this is because, first of all, know-how is previously unknown information, expressed in various forms, to increase commercial potential. At the same time, the current legislation of Ukraine does not provide for the provision of a patent, certificate or other official documents for such information to the creator, in particular, there are no special rules of law that would regulate the relations of persons related to protection thus, such protection occurs according to the general rules established for the protection of intellectual property rights. Thus, to simplify the legalization of know-how, its protection, and further protection as an object of intellectual property rights, its creators resort to identification with trade secrets.

Many scientists (section - III. B. Analysis of Recent Research and Findings), the authors believe that the trade secret is a much broader concept than know-how, so they cannot be identified. At the same time, the protection of know-how as a component of trade secrets does not contradict the general dialectical principles and the current legislation of Ukraine, which allows us to conclude that the author of know-how can determine whether this information is a trade secret or will be called "know-how".

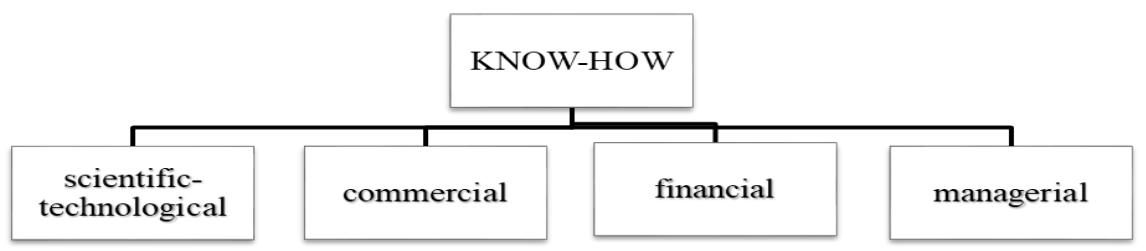

Fig. 3 The classification Main features of the innovations in the banking sector (Own creation). 
Know-how can be classified according to its main purpose into (Fig. 3):

1. Scientific-technological know-how is closest to the patentable result of activity and is a technological solution to a certain actual existing problem;

2. Commercial know-how concerns the sale of products or services;

3. Financial - will allow using the available funds;

4. Managerial know-how is usually manifested in the development and application of productive and effective management structures and methods, simple, clear, and reliable structural links both vertically and horizontally, in a clear division of responsibilities, functions, and powers, in functional interaction of structural units and enterprises cooperating with each other (Matviychuk et al., 2015).

In the future, the symbiosis of new and currently known and used technologies of banking services will be based on methodological and structural-technological transformation of the bank's head, front and back offices, which is based on a clear division of powers and functions. That is why managerial know-how deserves special attention among banking innovations.

In the banking sector, scientific-technological know-how is not used often enough, while other types of it productively support the activities of banks.

Thus, the know-how of the banking segment is manifested in the creation of a banking product or service in a new market sector and a new banking product or service in the traditional market, the use of previously unknown methods and ways of managing funds through information technology, the transformation of financial intermediation services aims to reduce the number of transactions and increase the efficiency of asset and financial liability management.

In practice, know-how in the field of IT, as previously unknown knowledge, is often modified into a new banking product or service that is gradually introduced to the market (fig. 4). 


\section{Typical forms of performing know-how in the banking sector}
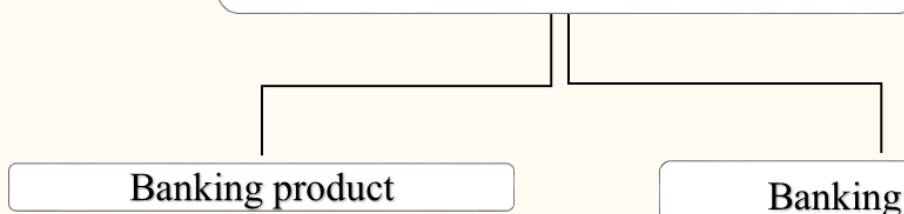

Banking product

Banking service

Fig. 4 The forms of know-how in the banking sector (Own creation).

Another thing should be mention that the effective innovation IT is possible only if the optimal organization of the innovation process. The scheme of implementation of the banking innovation process can be depicted as follows (Fig. 5).

\begin{tabular}{|c|}
\hline Goal setting \\
\hline Determining the possibility of its implementation \\
\hline Determining the conditions and organization of implementation \\
\hline Internal control and external regulation \\
\hline
\end{tabular}

Fig. 5 The implementation of the banking innovation process (Own creation).

Following this algorytm (Fig. 4), in 2014, PrivatBank at the Finovate Spring 2014 Banking Innovation Forum in San Jose, California, presented its development to the world community - the world's first contactless Android ATM, which in its functionality allows the use of a smartphone keyboard or Google Glass for receiving cash. This innovation received the status of the winner of the forum by voting, and its creative presentation the Best of Show award (Zolotareva, 2016).

This confirms that IT plays an important role in the established reputation of each bank and the banking system as a whole. 
Active use of IT is typical for most developed countries. The idea of the American company Socure to implement the Perceive project in the banking sector is interesting, which will provide an opportunity to use photos on social networks Facebook, Twitter, and LinkedIn to identify the client for his authorization in the mobile banking application. This will allow you to abandon complex passwords and significantly speed up the login and confirmation of further actions in it. Thus, the photo taken on a smartphone by the program "Perceive" will be compared with the image of a person on social networks, which will avoid doubts about the user's identity of the bank's customer.

No less unique is the IT proposed by Union National Bank (UNB), one of the leaders in the UAE financial services market, to reduce the possibility of fraud. This IT relates to the method of verifying the signature in a check with an electronic sample stored in the database and consists of a fully automatic verification of the signature by the system, which minimizes the possibility of error (Kiselyov, 2019).

Without information technology, it would not be possible to implement, in particular, mobile banking; Internet banking; "Zone 24"; electronic balance; POS-terminals, which are the most successful results of the introduction of innovations in banking.

The example of mobile banking clearly illustrates the dependence of the introduction of IT on the development of other spheres of society. Thus, the use and distribution of smartphones has created the possibility of mobile banking as such, as it is based on the idea of replacing a plastic card as a method of payment. Users of mobile banking can easily pay for goods and / or services using mobile phones with the appropriate aids.

At the same time, mobile banking exists thanks to such modern technologies as NFC, QR-codes, and GPS. For example, NFC short-range wireless high-frequency technology allows you to download payment details to your smartphone and pay for goods by swiping your phone over a POS terminal. That is, the client is identified using NFC-chips, which are built into the phone.

Besides, e-banking is an indispensable assistant in the automatic payment of utility bills, interest payments on loans, purchase of any goods or services online, and so on.

In light of recent developments in the spread of acute respiratory disease COVID-19 caused by the coronavirus SARS-CoV-2, the above banking innovations not only serve to comfort the user but also protect him from infection by minimizing the possibility of user contact with other persons or objects to meet his daily needs.

Thus, the introduction of IT in the banking sector is one of the main tasks of translating all possible banking services into digital format. 
Experts predict that digital banking services will be the main way to interact with the bank. However, some factors negatively affect the state of innovative development of electronic banking in Ukraine:

1. lack of a clear position of the legislator, which would be expressed in regulations on the regulation of legal relations between banks and their customers in the process of using electronic banking.

2. Low level of customer confidence in Internet technological innovations and low level of awareness of certain groups of the population about the possibility and procedure for their use.

3. Limited internet access.

The other significant reason for suspending the development of innovatively modified forms of e-banking is financial and political instability in Ukraine, which results in unfavorable conditions for the banking sector and sometimes leads to the liquidation of banking institutions and the withdrawal of foreign banks from the domestic financial services market. In this situation, the small number of banks, that actively implement innovations and invest in favor of their development, carries great risks and remains in the minority in our country (Dominova, 2016).

At the same time, according to the authors, the functioning of the "bank without branches" - Monobank in Ukraine today should be considered indicative within the application of know-how. The fact is that the Monobank system is almost entirely built on information technologies, ranging from completely remote service by the bank and ending with banking products offered to customers. Adherence to such implementations is vividly illustrated by the Fig. 6 , which allows us to understand the volume and speed of user connection to Monobank since the beginning of its beta testing in October 2017.

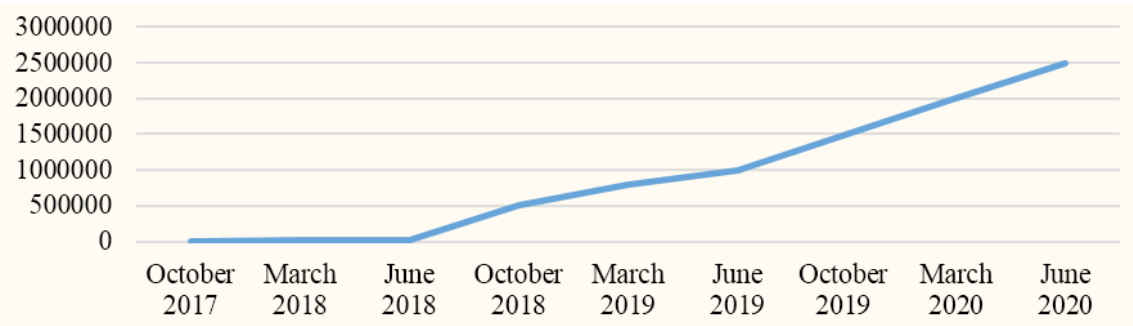

Fig. 6. Number of Monobank users 2017-2020, data provided by Monobank (2020). 
The introduction of information technologies in banking directly depends on the innovation policy pursued by the respective bank. This policy forms the technological component of innovative development of the banking system, which is primarily manifested in the management process, based on the constant search and implementation of previously unknown ways and areas of realization of the potential of the economic object according to the chosen mission and motivation in changing environmental conditions (Global FinTech Adoption Index, 2020).

The era of information technology has allowed expanding the variations of know-how, in particular with the use of blockchain technology, which can become a platform for effective management in all vectors of bank core management (core banking system) and in working with consumers. Blockchain is positioned as a database designed to store information and verify transactions. The uniqueness of this technology is the inability to make changes to already performed processes, which in turn protects against the risks of deleting information about a transaction, ensuring the transparency of each operation.

The active use of blockchain will give impetus to the transition to today's advanced digital technology called "Big data", i.e. the collection, accumulation, processing, and use of large arrays of information (Tkachenko and Zveruk, 2018). With the help of Big Data and deep machine learning algorithms, banks supplement standard risk algorithms with new procedures that can significantly improve the predictive power of the models used (Sadchikov, 2018). Thanks to analytical tools, banks start dealing with arrears even before the borrower breaks the payment schedule. The system examines various parameters, such as the rate at which the credit card limit is drawn, the frequency, and the volume of payments. This is how banks identify those who are about to miss a payment.

At the same time, according to the author, in the further formation of innovation policy, banks should focus on the introduction of know-how aimed at creating and maintaining the maximum level of protection of personal data of customers. Banking information technologies also serves to establish effective communication channels, increase the level of digital, economic, and financial awareness of the population, reduce the costs of the banking institution to create and strengthen the image and reputation, expand and optimize the array of banking products and services. For customers, the above information technologies facilitate access to the information they need, provide an opportunity to economically use their own time and money for bank services (Pidvysotsky, 2014).

Thus, in today's conditions, the guarantee of stable and promising operation of the banking sector is the development and implementation of innovative strategies aimed at achieving maximum consumer value for participants in banking relations, which will create and maintain a competitive advantage in the long run (Ostash, 2015). 
Ernest Gramatskyy, Inha Kryvosheyina, Volodymyr Makoda y Liydmyla Panova

\section{Conclusions}

1. The use of know-how in the field of IT is currently enhanced by the lack of proper legal regulation of this object of intellectual property rights, in particular, on how to protect it. Thus, know-how is often protected as a trade secret or object of copyright, but at this stage of dissemination of know-how, these methods of protection are not able to fully cover the full range of characteristics of the latter, and therefore should consider the prospect of definition and final consolidation of know-how as an independent object of intellectual property rights, which will have its own individually defined methods of protection in case of infringement of copyright.

2. Innovative information technologies play an important role in the banking sector. Thus, banking know-how aims to:

- Implementation of "multi-channel activities" in the interaction of generally accepted and newly created technological tools.

- Development of virtual network banking and financial implementations: bankaccountmanagement, cash settlements, electronic signature, the conclusion of agreements, financial organizations (exchanges, banks).

- The combined use of new information and communication technologies for electronic and mixed (traditional and new) marketing.

- Creation and introduction of new banking products (services) based on new technologies.

3. Banking information technologies is also designed to maintain the country's image at the global level, increase confidence in the banking sector, and establish the most convenient interaction with its customers. This requires the introduction of active innovation policy in banks, as well as support within their implementation by the state.

4. With this in mind, know-how should be the "lion's share" of the assets of any commercial organization, including the banking sector, which plans to operate on the platform of a high-tech economy.

The vector of further research within this subject concerns, first of all, the support of innovation policy both by the banking institutions themselves and by the state; active use of modern digital technologies, in particular blockchain technologies, as a platform for creating know-how; increasing the level of "openness" of users for the introduction of banking innovations; 
improving the legal regulation of personal data protection in the banking sector through know-how.

\section{Bibliographic References}

ARISTOVA, Iryna; CHERNADCHUK, Victor. 2012. "The concept of information relations: the essence and features of use in the field of banking" In: Information and Law. Vol. 3, No. 6, pp. 47-56.

BEGOVA, Tetiana. 2009. The concept of "know-how" and the agreement on its transfer. Law. Kharkiv, Ukraine.

BEGOVA, Tetiana. 2019. "To the question of the concept of "know-how" as an object of intellectual property rights" In: Entrepreneurship, economy and law. Vol. 5, pp. 23-26.

DAVYDOVA, Iryna; ORZIKH, Yurii; SAMOYLENKO, Georgiy; ANDRONOV, Ihor; PYSARENKO, Maryna. 2019. "Legal Consequences of the Invalidity of a Transaction made by Using Information Technology: Problems of Theory and Practice” In: Amazonia Investiga. Vol. 8, No. 19, pp. 613-619.

DMITRENKO, Viktoria. 2016. "Problems of know-how regulation in the legal system of Ukraine" In: Theory and practice of intellectual property. Vol. 2, pp. 58-66. Available online. In: http://www.inprojournal.org/ wp-content/uploads/2017/01/Dmytrenko.pdf. Consultation date: 20/01/2020.

DOMINOVA, Inna Volodymurivna. 2016. "Forms of electronic banking: evolution, advantages and disadvantages" In: Accounting and Finance. Vol. 2, No. 72, pp. 104-109.

GLOBAL FINTECH ADOPTION INDEX. 2020. Available online. In: https:// www.ey.com/en_gl/ey-global-fintech-adoption-index. Consultation date: $12 / 12 / 2019$.

KISELYOV, Andrii Vasyliyovich. 2019. State regulation of innovative development of the market of banking services of Ukraine. Inter. Kyiv. Available online. In: https://nam.kiev.ua/files/tesis/dyss-kiseliov.pdf. Consultation date: $20 / 01 / 2020$.

KOLOSOV, Oleksander. 2017. Determinations and the legal regime of knowhow in Ukraine. Available online. In: http://kolosov.kiev.ua/file/ shop/318_1.pdf. Consultation date: 20/01/2020. 
Ernest Gramatskyy, Inha Kryvosheyina, Volodymyr Makoda y Liydmyla Panova

KUNTSEVICH, Volodymyr. 2005. “About know-how” In: Intellectual property. Vol. 4, pp. 32-38.

LAW OF UKRAINE. 2002. On innovation activity. Vidomosti Verkhovnoi Rady Ukrainy (VVR), 2002, $\mathrm{N}^{0}$ 40-IV. Available online. In: https://zakon. rada.gov.ua/laws/show/40-15\#Text. Consultation date: 20/01/2020.

LAW OF UKRAINE. 2006. On state regulation of activities in the field of technology transfer. Vidomosti Verkhovnoi Rady Ukrainy (VVR), 2006, No 143-V. Available online. In: https://zakon.rada.gov.ua/laws/ show/143-16\#Text. Consultation date: 20/01/2020.

MATVEEV, Petro Sergiiovich. 2015. "Theoretical and legal aspects of protection and defense of know-how and trade secrets as objects of intellectual property law in the innovative vector of economic development" In: European perspectives. Vol. 2, pp. 99-106.

MATVIYCHUK, Nikolai; BURLACHUK, Nazar; GARBAR, Zhanna. 2015. "Development of innovations in the modern banking sphere of Ukraine" In: Young scholar. Vol. 5 (20), pp. 28-30.

MONOBANK. 2020. Available online. In: https://www.monobank.ua/. Consultation date: $20 / 01 / 2020$.

NOSIK, Yuliia. 2007. Rights to trade secrets in Ukraine. KNT. Kyiv, Ukraine.

OSTASH, Serhii Vasyliyovich. 2015. "Banking innovation and some ways to improve its management” In: Scientific Bulletin of Uzhgorod University. Vol. 1, No. 45, pp. 227-230.

PIDVYSOTSKY, Roman. 2014. "Information innovations - a tool for effective interaction of the bank with customers" In: Bulletin of the National Bank of Ukraine. Vol. 4, pp. 66-67.

ROMASHKO, Anton; VERBA, Irina. 2013. "Know-how as a consequence of intentional incomplete disclosure of the invention (utility model)" In: Industrial hydraulics and pneumatics. Vol. 1, No. 39, pp. 13-15.

SADCHIKOV, Oleksander. 2018. Some of our know-how seems fantastic today. In: Banking Review. Available online. In: https://bosfera.ru/ bo/nekotorye-nashi-nou-hau-kazhutsya-segodnya-fantasticheskimi. Consultation date: 12/12/2019.

SHMIGELSKA, Zoriana. 2014. "Banking innovations: essence, necessity and development" In: Bulletin of the National Bank of Ukraine. Vol. 2, No. 216, pp. 34-41. 
SHYSHKA, Roman; TKALYCH, Maxym. 2020. "The World in 2020: What are the Tthreats to humanity?" In: Amazonia Investiga. Vol. 9, No. 26, pp. $3-5$.

SVISHCHOVA, Nataliia; CHEREPANOVA, Vladyslava; LOKTIONOVA, Olena. 2017. "Know-how: concepts, methods of protection and role in enterprise management" In: Bulletin of NTU «Kharkiv Polytechnic Institute». Vol. 45, No. 1266, pp. 93-96.

TKACHENKO, Yuliia; ZVERUK, Ludmyla. 2018. "Modern technologies as a basis of innovative model of banking business development" In: Economic theory and law. Vol. 2, No. 33, pp. 26-38.

TKALYCH, Maxym; SAFONCHYK, Oksana; TOLMACHEVSKA, Yuliia. 2020. "Derecho privado y derechos humanos: Nuevas realidades" In: DIXI. Vol. 22, No. 2, pp. 1-12.

ZOLOTAREVA, Olga; Chekal, Anastasiia. 2016. "Innovative banking products and the specifics of their implementation in Ukraine" In: Scientific Bulletin of Kherson State University. Vol. 16, No. 1, pp. 112-115. 

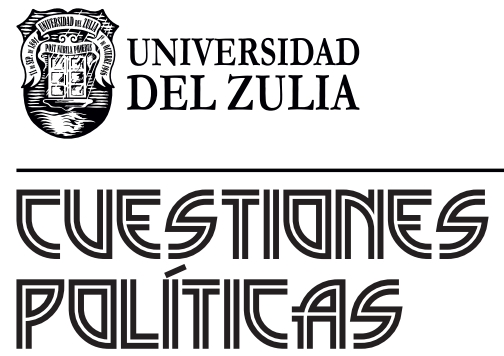

Vol.38 NEspecial

Esta revista fue editada en formato digital y publicada en diciembre de 2020, por el Fondo Editorial Serbiluz, Universidad del Zulia. Maracaibo-Venezuela 